\title{
Primary cutaneous aggressive epidermotropic CD8+ T-cell lymphoma
}

INSERM

\section{Source}

INSERM. (1999). Orphanet: an online rare disease and orphan drug data base. Primary

cutaneous aggressive epidermotropic CD8+ T-cell lymphoma. ORPHA:178528

Primary cutaneous aggressive epidermotropic CD8+ T-cell lymphoma is a rare form of primary cutaneous T-cell lymphoma characterized by rapidly prog ressing, localized or disseminated nodules, tumors or eczematous skin lesions. It has a particularly aggressive clinical course with a high tendency to spread, in advanced stages, to extracutaneous locations (the central nervous system, lung, testes). Lymph nodes are often spared. 